Occultations of Stars by the Moon (visible at Greenwich)

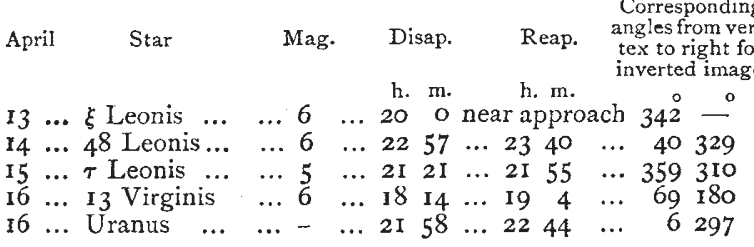

$\begin{array}{ccccc}\text { April } & & \text { h. } & & \\ 16 & \ldots & 12 & \ldots & \text { Jupiter in conjunction with and } 0^{\circ} 29^{\prime} \text { north }\end{array}$ of the Moon.

\section{Meteor Showers}

Amongst the radiants represented at this season are the fol lowing :-Near $\psi$ Ursæ Majoris, R.A. $162^{\circ}$, Decl. $48^{\circ}$ N.; from Coma Berenices, R.A. $190^{\circ}$, Decl. $21^{\circ}$ N.; from Libra, K.A. $225^{\circ}$, Decl. $5^{\circ}$ S. ; from Corona, R.A. $240^{\circ}$, Decl. $25^{\circ}$ N.; from Hercules, R.A. $265^{\circ}$, Decl. $23^{\circ}$ N. ; maximum April 13 .

\section{GEOGRAPHICAL NOTES}

THE sixth German "Geographentag," which will be held at Dresden on the three last days of this month, together with a Geographical Exhibition, will, first of all, bring up the reports of the two travellers, Messrs. Reichard and Lieut. von François, concerning their experiences and observations in Equatorial Africa. Dr. Ed. Naumann will speak on his topographical and geological survey of Japan, and Director A. Matzat, of Weilburg, on drawing in geographical instruction. Further addresses which will be delivered are by Dr. G. Leipold (Dresden), on the raising of the sea-level near the coasts of continents; by Dr. Hahn (Königsberg), on the development and division of coasts from a geographico-com nercial point of view; by Dr. P. Lehmann (Berlin), on the significance of Kant for geographical science; by Dr. Egli (Ziirich), on the development of the nomenclature of towns, \&c. ; by Dr. Petri (Berne), on the exploration of Siberia ; by Dr. O. Schneider (Dresden), on the closer limitation of geographical terms ; and by Dr. S. Ruge (Dresden), on the Central Commission for German topography.

A LE'TTER was recently read before the Russian Geographical Society on March I7 from M. G. N. Potanin, the leader of another Expedition to Central Asia. At the end of October last the explorer was on his way from Sukhan-Hiln to Lon-djou. He had met great difficulties on this journey; the Expedition having been compelled to march on foot and their luggage to be carried by porters. The direction of the return journey will depend on the success of the proposed passage across the Desert of Gobi. However, this return is secured.

WE have received a communication from M. Grigoriev, Secretary of the Imperial Russian Geographical Society, in which he informs us that Dr. Bunge has left Nasàtchyé, his headquarters, on the Yana River, in command of the Expedition to explore the New Siberian Islands during the summer, and that he is expected back at the end of October or early in November. These islands, which by many Arctic explorers are held to be the right base for an attack on the Pole, are very little known, not having been visite 1 since 1823 .

THE Norwegian Storthing has granted a sum of $45 \mathrm{col}$. towards the further geographical survey of Norway.

Mr. C. WinNeCkE, of South Australia, has prepared a plan showing the contour of the country along the overland telegraph line from Port Augusta to the Queensland boundary, a distance of 1626 miles.

THE SAHARUNPUR BOTANICAL GARDENS $M$ R. J. F. DUTHIE'S Report on the progress and condition of the Government Botanical Gardens at Saharunpur and Mussoorie for the year ending March 31, I885, has reached us. It is a bulky Report of some fifty-one pages and a very interesting Report of fifteen pages, on "an examination of the indigenous grasses and other fodder-yielding plants growing on the Hissar Birland," under date September 5, 1885, accompanies it. In the Report on the Gardens, amongst other interesting and im- portant matters Mr. Duthie refers to samples of wheat and barley grown in the Saharunpur Garden, which had attracted some amount of attention in this country. He says :-- " Amongst some contributions for the Eçnomic IMuseum of the Royal Gardens, Kew, which I took to England last year were two samples of grain-one of a variety of wheat called 'Gujaria,' and grown at Saharunpur from selected seed, the original having been received some years since from the Government Farm at Cawnpore; the other a remarkable variety of loosegrained barley, of a dark chocolate colour, from a small sample exhibited at a previous agricultural show at Saharunpur." These samples were considered by the authorities at $\mathrm{Kew}$ to be of sufficient interest for their being specially reported on, and they were accordingly sent to Messrs. McDougall Bros., of Millwall Docks, who reported to the effect that the samples had been shown to most of the principal people on the Corn Market, who took much interest in them. The wheat was valued at about 30s. per $496 \mathrm{lbs}$, it being classed with the Kubanca (Russian) wheat, its bright and clean appearance causing much remark. On grinding and pasting it was found to contain much gluten, but to be somewhat sticky. The reporter thinks, however, that it would pay better to grow the white seed, such as is now shipped from B $>$ mbay, and realises $39 s$. per $496 \mathrm{lbs}$. Regarding the barley, the specimen, it is said, was looked upon with much interest, and many opinions expressed upon its being quite new, and the value varied from $23 \mathrm{~s}$, to $30 \mathrm{~s}$, per $400 \mathrm{lbs}$. On damping, the grains were found to sprout well, and so would do for malt, but the colour comes off, and so would not do (it is thought) for pale ales, but it might do well for stout ; for feeding purposes it would be useful, although it would take time to remove prejudice against its colour. In some comments on this Report Mr. Duthie says:- "The wheat is a very hard freegrowing sort, and always gives a good yield, both in grain and chaff. Last season the yield was 18 maunds and 13 seers chaff per acre. This variety possesses the good quality of being able to stand well up when grown in highly-manured soil; for, as is well known, most varieties of Indian wheat run up into straw and fall over before coming to maturity when the soil is toc highly manured. This variety is thus well-adapted for those who attempt to cultivate wheat according to the European method. The chocolate-coloured barley produced 15 maunds grain and $12 \frac{1}{2}$ maunds straw per acre. The yield of grain was thus heavier than the yield of straw. The objection as to colour, alluded to in the Report, is fatal to its value, and will prevent its ever being grown except as a curiosity. We possess a white-grained variety of huskless barley, and a good large sample of this has lately been sent to Kew for special report. The huskless barleys appear to be quite unknown in England, and as everything except colour was favourably commented on in the case of the variety sent, I am in hopes that the report on the white variety will be altogether favourable, and perhaps become the means of bringing the barley to the notice of the English market." Mr. Duthie records the introduction of many useful and ornamental plants to the Gardens; and to the Herbarium, he says, large and valued contributions continue to be received, amongst them a very interesting set of specimens from Mr. C. B. Clarke, chiefly belonging to families which have been specially worked up by him in his several monographs contributed to the "Flora of British India" and De Candolle's "Prodromus," also a large collection made by Mr. J. S. Gamble during a tour in the Madras Presidency. Besides which duplicates had been received from Dr. King, of the Calcutta Botanic Garden, and Dr. Trimen of the Peradeniya Botanic Garden, Ceylon. In addition to these contributions, specimens had been placed in the Herbarium collected during Mr. Inthie's expedition to North-Eastern Kumaun. This collection, it is stated, "consists of over 1000 species and varieties, including about 25 new to science, one (Cystopteris montana) new to India, and upwards of 128 not previously recorded for Kumaun. The north-eastern portion of Kumaun, including the districts of Dárma and Byáno, had not hitherto been explored botanically, and this, of course, accounts for the large number of new records. Amongst these latter are several which harl previously been known only from Nepal and Sikkim. Further investigation will, no doubt, confirm my own conclusions as to the greater similarity of the vegetation along the entire length of the Himalayas as you approach the inner and drier ranges." Mr. Duthie's "Appendix VI.," being "Notes on a Botanical Expedition to North-Eastern Kumaun in $\mathbf{1} 884$," will be read with interest by the botanist interested in Indian plants. 